\title{
The degree of flammability for an artificial grass surface system
}

\author{
Bozena Kukfisz, ${ }^{1, *}$ \\ ${ }^{1}$ The Main School of Fire Service, Faculty of Fire Safety Engineering, Slowackiego Street 42/54, 01- \\ 629 Warsaw, Poland
}

\begin{abstract}
The paper presents a general overview of sport and floor lining products, such as artificial grass, which are used in residential premises and public utility buildings, as well as the hazards which ensue from the use of synthetic grass [1]. An outline was made of the requirements for the fire safety of civil engineering structures arising from their designation and usage type. The results were presented from studies conducted on four samples of synthetic grass with the main ingredients being polyethylene and polypropylene. An appraisal method was determined for flammable properties and flame spread on a horizontal sample subjected to a heat radiation flux gradient in a research chamber pursuant to PN EN ISO 92391 [25] applicable for all types of floors. Based on the estimated value of critical heat radiation flux (KSP) below $3 \mathrm{~kW} / \mathrm{m}^{2}$ and in addition to the flammability of products directly subjected to a flame according to PN EN ISO 11925-2 [27], a study was made of the suitability of selected samples of artificial grass by their categorisation to class $E_{f l}-$ i.e. easily flammable products. The classification of artificial grass selected for the needs of the studies, which has been verified in practice, and designated for use as decoration for gazebos, balconies, terraces and public utility facilities is only admissible in residential premises of type ZL IV.
\end{abstract}

\section{Artificial grass base - general overview}

Currently, for practical reasons, there is a trend of replacing natural grassy surfaces on balconies, terraces, offices as well as sport stadiums with lining made of plastics "artificial turf" [2]. Artificial grass systems are among others used for the establishment of football fields, tennis courts, golf fields and playgrounds.

Artificial turf mats consist of a substrate and of a web of synthetic fibres that form a surface layer imitating grass thanks to its colouring. Appropriate brushing during the laying process allows pulling out fibre ends to the surface and this allows forming a top surface that imitates grass. The basic component of a third generation artificial turf system in the sequence of laying is its flexible base up to $10 \mathrm{~cm}$ thick, green lining with smooth or twisted fibres with a pile height of up to $60 \mathrm{~mm}$, mineral filler up to $15 \mathrm{~mm}$ thick and green granulate up to $25 \mathrm{~mm}$ thick. The continuous development of artificial lawns allowed the production of 4 th generation lawns, the so-called unfilled grass. In this type of grass surface

\footnotetext{
*Corresponding author: bkukfisz@sgsp.edu.p1
} 
the function of filling (sand and granulate) was replaced by a dense structure of twisted fibres, and monofilament fibres form the web [3,4].

Fibre bundles are braided into the supporting surface, which has openings for rainwater drainage. The supporting surface consists of the first and second base. The first base may be constituted by a warp stranded from UV stabilised PP or from glass fibre, or in addition a layer of polyethylene terephthalate (PET) may be used. The second base is a layer that reinforces the system, which is made of latex with the potential addition of styrenebutadiene rubber (SBR) or polyurethane (PU) $[1,5,6]$.

The web is most frequently made of polypropylene (PP), polyethylene (PE), PE and PP copolymer, polyamide (PA) or nylon (PA6) and may also consist of a mixture of polyethylene, polypropylene or nylon fibres. For the production of sport surfacing use is made of monofilament fibres or fibrillated fibres. Monofilament fibres may have an oval, rectangular, triangular section, and may be executed in a $\mathrm{V}$ or $\mathrm{C}$ shape (arch-like), propeller shape (S-shaped), diamond shaped and so on. Monofilament fibre is made of a bundle of single straight or twisted fibres with a thickness up to $240 \mu \mathrm{m}$, which may be reinforced by special cores immersed in their structure to improve their system rigidity, and fibrillated fibres consist of nicked tapes around a dozen millimetres wide, with a maximum thickness up to $100 \mu \mathrm{m}$. Depending on the notching method, the tapes have a yarn type structure or a system resembling monofilament fibres. Fibrillated fibres may become split during brushing performed during maintenance operations, and as a consequence in conditions of their use the effect of surface "closing" occurs, which are phenomena that are not observed in the case of the usage of monofilament fibres. Monofilament fibres offer parameters similar to natural grass, are resistant to abrasion, however, disadvantages in their use include the heating up of the surface and the leaking of rubber filling. Given the advantages and drawbacks of fibres used in the production of sport linings, monofilament fibres and fibrillated fibres may be joined with one another, in such a way creating a "vario" surfacing, the application of which limits the heating up of the surface and keeping the granulate inside the lining, which improves the flexibility and elasticity of such sports surfacing or other types of lining $[4,5]$.

Fillers for synthetic grass, the so-called "infill", may consist of mineral or synthetic fillers. Mineral filler is made of rounded quartz sand with a layer thickness up to $15 \mathrm{~mm}$ or of ground coconut fibre with mineral filler (the so-called ecological filler -ECOFILL granulate). Synthetic filler may be made of SBR, e.g. one obtained from the recycling of used low-pressure tyres or technical rubber (the basic raw material is a mixture of SBR and natural rubber, and unfortunately causes an unfavourable smell, especially at higher temperatures) or of ethylene propylene diene monomer (EPDM) following the recycling of waste based on EPDM rubber (grey or black) or in the production process from a new mixture, called virgin (with full colour scheme), as well as of thermoplastic polyester elastomer (TPE) $[2,4,7,8]$.

Taking into account the components of artificial turf systems, especially SBR from recycled tyres and plastics such as TPE and EPDM, there is an ever increasing concern for potential environmental and health hazards. The most important pollutants that can be released from synthetic surfaces and surfacing are compounds of zinc of the zinc oxide used as a catalyser in the vulcanisation process [2], using polycyclic aromatic hydrocarbons (PAH) as softeners [9], volatile compounds and such admixtures, as benzothiazole, as well as aniline and phenol $[9,10]$. Literature presents information from a risk assessment related to the surrounding air over pitches of artificial grass made of recycled rubber, and the risk of cancer was found to be $1 * 10^{6}[11]$. However, to date not much information has been gained as to the ecological and toxicological consequences arising from the use of artificial turf $[5,6,9-12]$. The main part of studies in this respect is focused on an assessment of the ecotoxicity of rubber used for tyres. What is more, literature offers information regarding 
requirements for the synthetic surfacing of outdoor sports facilities depending on their usage (hockey, tennis, multisport, football and rugby) and whether they general requirements, such as resistance to artificial aging, water permeability, strength of connections, wearing resistance, compressive strength and additional requirements, which may include vertical rebound of a ball, vertical deformation, strength in rotating movement, simulation of wearing by sports shoes with studs, ball rolling, shock absorption and others $[4,13,14]$.

As artificial turf is produced of plastics, it is a material clearly susceptible to ignition. The burning-behaviour is a technical property, which is difficult to both test and evaluate [15]. These difficulties become apparent when we consider the long process of European standardization as well as the considerable variety of existing standards worldwide. It seems essential to define a proper laboratory test according to the fire risk scenario for the specific material considering the intended construction or facility design in order to reach a high level of security. As a side aspect of security it should be mentioned that this must include the determination of escape-routing and its simulation (fire drills). When we talk about the indoor application of artificial turf, we will have a different risk scenario than for the one designated for outdoor. It is obvious that there will be the need for specially developed materials to reduce the spread of flames and the control of smoke generation. The paper presented requirements with respect to criteria that have to be met by a product used as floor lining in a facility, including fire properties with respect to resistance to external ignition sources have currently available artificial turf systems used in public utility facilities and residential buildings.

As regards requirements related to materials /construction products used in buildings, in the understanding of the act [16], which clearly defines civil technical structures, a building structure was determined, including a building for which the building material/product is to meet relevant requirements. General requirements as regards fire safety, despite for example of the lack of detailed data pertaining to the building, does not release one from the statutory necessity of meeting fire safety requirements specified by the above mentioned act $[16,17]$.

\section{Requirements for the fire safety of buildings or their parts where artificial grass base may be used, arising from their designation and occupancy type}

Pursuant to regulation [18] a building, and all systems associated with it, should be designed and executed in a way that assures structural bearing in case of a fire for a time specified by the above mentioned regulation, the limitation of fire and smoke spreading inside the building, limiting the spreading of fire onto adjacent buildings, the possibility of evacuating people, and should also allow for the safety of rescue teams. Adhering to requirements specified in the regulation also requires allowing for separate regulations pertaining to fire protection, which define among others, the requirements of Polish standards and criteria specified in appendix No. 3 to regulation [18], concerning in particular, rules for the determination of the reaction to a fire in building products (materials) and the toxicity of the decomposition of products in the combustion of those materials.

Buildings and parts of such buildings, which form individual fire zones taking into account designation and occupancy, are divided into residential facilities, collective residential buildings and public utility buildings characterised by a hazard category for people hereinafter called ZL; production and warehouse facilities further referred to as PM, and livestock housing (used for livestock breeding) further called IN. Buildings and parts of 
buildings forming separate fire zones are defined as ZL, and are categorised by one or more category of hazard for people.

Requirements of the above mentioned regulation [18] to meet fire protection requirements in ZL I, ZL II, ZL III, ZL V (lack of requirements for ZL IV) for elements of interior finishing and permanent fit-out. In fire zones ZL I, ZL II, ZL III, ZL V the use of easily flammable products and materials for interior finishing, whose thermal decomposition of products are highly toxic or smoke,intensively is inadmissible. However, it is necessary to bear in mind that the next requirement related to assuring safe evacuation, for easily flammable building materials and products that may not be used on general communication roads used for evacuation purposes. The next provision of the requirements refer to floor linings and takes into consideration the number of people inside a premise (not necessarily in the entire zone or storey of the building). In premises designated for the concurrent presence of more than 50 persons and in production premises, the use of easily flammable partitions, fixed furnishing elements and interior decoration, as well as floor lining is not allowed. Consequently in fire zones ZL I, ZL II, ZL III, ZL V, if more than 50 persons are inside at the same time, and in production premises regardless of the number of people the usage of easily flammable artificial turf mats is prohibited, and the only factor that can release one from the adherence to this requirements is classification of a product as flash resistant.

When analysing ways that a floor product reacts to fire, it is necessary to follow the rules specified in the standard [19], which categorises flooring and floor covering into seven classes: $\mathrm{A} 1_{\mathrm{fl}}, \mathrm{A} 2_{\mathrm{fl}}, \mathrm{B}_{\mathrm{fl}}, \mathrm{C}_{\mathrm{fl}}, \mathrm{D}_{\mathrm{fl}}, \mathrm{E}_{\mathrm{fl}}$ and $\mathrm{F}_{\mathrm{fl}}$. Another classification method (table 1) is testing the reaction to a fire and on this basis determination of the flammability degree of the material as specified in regulation [18].

Table 1. Classification of flooring products by their flammability [18, 19].

\begin{tabular}{|l|l|}
\hline Determination for flammability [18] & Classification to fire [19] \\
\hline Non-flammable & $\mathrm{A} 1 \mathrm{fl} ; \mathrm{A} 2 \mathrm{fl}-\mathrm{s} 1 ; \mathrm{A} 2 \mathrm{fl}-\mathrm{s} 2$ \\
\hline Slow burning & $\mathrm{B}_{\mathrm{fl}} \mathrm{s} 1 ; \mathrm{B}_{\mathrm{fl}}-\mathrm{s} 2 ; \mathrm{C}_{\mathrm{fl}}-\mathrm{s} 1 ; \mathrm{C}_{\mathrm{fl}}-\mathrm{s} 2$ \\
\hline Easily flammable & $\mathrm{D}_{\mathrm{fl}}-\mathrm{s} 1 ; \mathrm{D}_{\mathrm{fl}}-\mathrm{s} 2 ; \mathrm{E}_{\mathrm{fl}} ; \mathrm{F}_{\mathrm{fl}}$ \\
\hline Intensely smoking & $\mathrm{A} 2 \mathrm{fl}-\mathrm{s} 2 ; \mathrm{B}_{\mathrm{fl}}-\mathrm{s} 2 ; \mathrm{C}_{\mathrm{fl}}-\mathrm{s} 2 ; \mathrm{D}_{\mathrm{fl}}-\mathrm{s} 2 ; \mathrm{E}_{\mathrm{fl}} ; \mathrm{F}_{\mathrm{fl}}$ \\
\hline
\end{tabular}

Based on the above methods, a classification is made of materials if they are to be used inside a facility. On the other hand, from the viewpoint of the fire safety of sports facilities, and taking into consideration sports events organised in them, artificial turf should be resistant to ignition from maximum potential ignition sources that could occur during mass events. Such potential ignition sources comprise firecrackers or flares, according to recommendations of the International Federation Football Association, FIFA item 4.4 (Artificial turf playing fields. VII Safety and artificial turf pitches) from 2007 [3, 20], the combustion temperature of which may even reach $2000^{\circ} \mathrm{C}$. Firecrackers consist of a paper casing filled with black powder or even more frequently by photo-flash powder (such as class $3 \mathrm{CE}$ firecrackers). They are first of all meant to cause an acoustic effect. Standard [21] does not anticipate the possibility of firing firecrackers in a way other than with the use of a blasting fuse. Standard [22] allowed the use of a frictional element, which frequently burns at an uncontrolled rate causing various accidents. It should be borne in mind that FIFA regulations from 2011 comprise indications that, given the diversified building regulations and safety regulations in various countries, it is recommended assuming the most stringent safety criteria as a binding rule [23]. It should be borne in mind that the adoption of more stringent criteria for sports facilities comprises an analysis of susceptibility to ignition in the event of contact with material with a combustion temperature of ca. $2000^{\circ} \mathrm{C}$, and if artificial turf is used in residential buildings, this material may come into contact with a smouldering cigarette $\left(700-800^{\circ} \mathrm{C}\right)$, the flame of a match 
$\left(700^{\circ} \mathrm{C}\right)$, or the flame of burning newsprint paper $\left(700^{\circ} \mathrm{C}\right)$, which are sources that could be an effective ignition source $[3,24]$.

Requirements posed to evaluation methods of resistance to external ignition sources of artificial turf systems are met by the method used to test the surface flammability of flooring from the viewpoint of the fire hazard posed by them for civil structures. This standard specified the method for evaluating flammable properties and flame spread over a horizontal specimen subjected to the operation of a thermal flux gradient in the research chamber and with the use of a pilot burner, applied for all types of flooring, such as: textile lining, carpeting, of cork, wood or rubber. It is proposed that the suitability of material be evaluated by using the fire classification based on reaction to fire. The artificial grass system should be at least class $\mathrm{C}_{\mathrm{fl}}-\mathrm{s} 1$ determined only on the basis of tests by the method specified in PN EN ISO 9239-1:2010 Testing the reaction of flooring to fire- Part 1: Determination of fire properties of a radiating plate [25].

\section{Testing the reactions of floor lining consisting of synthetic turf to fire using the method of a radiating plate}

The basic testing comprised three samples of each type of artificial turf with dimensions of $(230 \pm 5) \mathrm{mm} \times(1050 \pm 5) \mathrm{mm}$. Testing was performed with the use of decorative artificial turf mats available in a majority of markets selling building products. The selected samples bore commercial names such as Summer, Isla, Bali and Porto and were chosen owing to their popularity and taking into account their designation (as a decoration for gardens, terraces or utility premises). Table 2 presented the features of specimens selected for testing. The thickness of the specimen with its undercoat did not exceed $60 \mathrm{~mm}$. The undercoat was a non-flammable fibre-cement panel pursuant to standard [26], which simulated real flooring and reflected its actual execution method. Samples of artificial grass selected for testing represented the real utility structure of flooring including the undercoat and mounting methods. The specimens were seasoned pursuant to requirements of standard [26] and air-conditions at the temperature of $(23 \pm 2)^{\circ} \mathrm{C}$ and at relative humidity $(50 \pm 5) \%$ for 48 hours, until permanent mass has been achieved.

Table 2. Description of samples chosen for testing.

\begin{tabular}{|c|c|c|c|c|}
\hline Name of sample & Bali & Isla & Porto & Summer \\
\hline Total thickness $[\mathrm{mm}]$ & 42 & 33 & 50 & 9 \\
\hline Pile height $[\mathrm{mm}]$ & 40 & 30 & 48 & 7 \\
\hline Number of points per $\mathrm{m}^{2}$ & 21000 & 18000 & 19900 & 10400 \\
\hline Composition & $100 \% \mathrm{PE}$ & $100 \% \mathrm{PE}$ & $100 \% \mathrm{PP}$ & $100 \% \mathrm{PP}$ \\
\hline Fibre/total weight $\left[\mathrm{g} / \mathrm{m}^{2}\right]$ & $1550 / 2600$ & $500 / 1415$ & $1720 / 2725$ & $270 / 1000$ \\
\hline Undercoat & grass preacoat & grass preacoat & grass preacoat & marine \\
\hline
\end{tabular}

In the testing a sample placed horizontally on the substrate was subjected to external thermal radiation flux with a standardised distribution along the tested sample (from 10.9 $\mathrm{kW} / \mathrm{m}^{2}$ to $1.1 \mathrm{~kW} / \mathrm{m}^{2}$ ) generated by a plate radiator with a flame that initiates combustion, supplied by propane. The source of thermal radiation was a radiator inclined at an angle of $30^{\circ}$ to a level with a flat radiation surface $(300 \pm 10) \mathrm{mm}$ wide and $(450 \pm 10) \mathrm{mm}$ high, which enabled obtaining the power of thermal radiation flux within the range from 45 $\mathrm{kW} / \mathrm{m}^{2}$ to $50 \mathrm{~kW} / \mathrm{m}^{2}$. Constant operating conditions of the radiator were regulated by the $\mathrm{NiCr}-\mathrm{Ni}$ thermocouple. The density of the thermal radiation flux was determined with the use of a Gordon-type disc converter with an accuracy up to $\pm 0.1 \mathrm{~kW} / \mathrm{m}^{2}$. The pilot burner was a pipe with two rows of evenly spaced openings with a diameter of $0.7 \mathrm{~mm}$. The burner was supplied with propane at a flow capacity of $0.026 \pm 0.002 \mathrm{dm}^{3} / \mathrm{s}\left(94 \pm 7 \mathrm{dm}^{3} / \mathrm{h}\right)$. During 
the testing, the flame spread along the sample in a direction consistent with the decreasing density of the thermal radiation flux until its automatic extinguishing.

After the lapse of 2 minutes and the initial heating of the sample, with the pilot burner raised at the level of $50 \mathrm{~mm}$ from the zero point of the test specimen, the pilot burner was lowered to have the flame touch the sample $10 \mathrm{~mm}$ from the holder edge. For the next 10 min burner flames were in contact with the sample. After that time the pilot burner has been drawn back to the initial setting and the gas supply to the burner was switched off. Every 10 minutes following commencement of the testing, and at the time when the flame went out, the distance between the zero point and the flame front was measured at an accuracy of 10 $\mathrm{mm}$. In addition, a record was kept of the time in which the flame achieved each of the marking points at the distance of $50 \mathrm{~mm}$ and the farthest situated point achieved by the flame front during the testing. According to the instructions the testing was finished after 30 minutes.

During the testing the critical heat flow (CHF) was determined, which indicates the lowest value of thermal radiation intensity of the sample of material being tested, at which flame ignition of the material takes place. CHF is characterised by resistance of the material to external ignition sources. This value is delimited by measuring the range of the flame, and then based on characteristics of the distribution of thermal flux along the sample the value of this intensity appropriate for this range. During the testing, values were also obtained that characterised smoke generation properties. A determination was made of the maximum value of the degree of light stream weakening through a layer of smoke flowing through the chimney (S) and the total weakening of the light stream during the execution of testing $(\mathrm{Sc})$.

Causing the ignition of the material requires the determination of the thermal energy value. The value of this energy may be a measure of resistance to external fire sources. It is called a heat that keeps up flame combustion - Qsb. It was assumed that the measure of heat maintaining the flame combustion of material was the average value of the product of thermal flux intensity and the time of its impact on the material surface, after which its ignition took place. The parameters of the heat supporting flame combustion (Qsb) and maximum heat release intensity $\left(\mathrm{q}_{\mathrm{p}}\right)$ were determined according to the currently withdrawn Polish standard PN-B-02854:1996 Fire protection of buildings - A method of testing the propagation of flames on floorings [28].

The final results of testing of the degree of surface flammability of artificial grass systems were presented in Table 3 .

Table 3. Results of the testing of flammable properties and flame spreading over the horizontal specimen of artificial grass subjected to the gradient of thermal flux in the chamber according to

\begin{tabular}{|c|c|c|c|c|}
\hline Measured value & Bali & Isla & Porto & Summer \\
\hline Critical thermal radiation flux $-\mathrm{CHF}\left[\mathrm{kW} / \mathrm{m}^{2}\right]$ & 1.9 & 1.2 & 2.1 & 2.1 \\
\hline $\begin{array}{l}\text { Heat supporting flame combustion- } \mathrm{Q}_{\mathrm{sb}} \\
{\left[\mathrm{MJ} / \mathrm{m}^{2}\right]}\end{array}$ & 3.427 & 1.430 & 2.685 & 1.693 \\
\hline Maximum heat release intensity $-\mathrm{q}_{\mathrm{p}}[\mathrm{kW}]$ & 4.03 & 6.06 & 5.16 & 4.07 \\
\hline Heat released by sample - $\mathrm{Q}_{\mathrm{t}}[\mathrm{MJ}]$ & 4.187 & 5.126 & 4.194 & 4.945 \\
\hline Maximum weakening of light stream $-\mathrm{S}[\%]$ & 46.05 & 25.50 & 52.75 & 8.75 \\
\hline Total weakening of light stream $-\mathrm{S}_{\mathrm{c}}[\% * \mathrm{~min}]$ & 426.40 & 54.70 & 485.15 & 28.15 \\
\hline Flame range $F_{s}[\mathrm{~mm}]$ & $<150$ & $<150$ & $<150$ & $<150$ \\
\hline
\end{tabular}

Each material has a characteristic value of external heat flux falling on the surface of the material, at which ignition takes place. In the tested samples CHF has not exceeded the value of $3 \mathrm{~kW} / \mathrm{m}^{2}$ which means that all the analysed samples of artificial grass have been 
categorised as class $\mathrm{E}_{\mathrm{fl}}$ according to standard [19] and have been considered as easily flammable. The most pronounced smoke generation properties were recorded for a sample of Porto, which may be proven by values of total light weakening (Sc) and weakening of the light stream through smoke (S), which for this specimen amounted to $485.15 \% *$ min and $52.75 \%$ respectively. Most likely, the greatest impact on the results of this measurement was exerted by the height of the pile in the samples. In addition a verification was made for categorisation of class $\mathrm{E}_{\mathrm{fl}}$ based on the flammability testing of building products subjected to the direct operation of a small flame, without the share of thermal radiation at vertical orientation of the specimens [27] at thermal exposition of 15 seconds and owing to the range of the flame smaller than $150 \mathrm{~mm}$ during 20 seconds class $\mathrm{E}_{\mathrm{fl}}$ has been maintained. Consequently, in fire zones of ZL I, ZL II, ZL III, ZL V, if over 50 persons are inside at the same time and in production premises regardless of the number of people, the use of, for example, a floor lining made of artificial turf which is easily flammable is inadmissible, and this obligation may only be waived if the product is classified as slow burning.

The performed testing enables studies of fire conditions in an early stage of fire development. The experiment allows a good reflection of the situation in communication pathways and in corridors It should be borne in mind, however, that the tested reaction of the material to the fire is performed on a laboratory scale, and so the testing results may refer to the behaviour of samples under specific testing conditions may not be the only criterion for the evaluation of fire hazard posed by the applied product, and may only be considered as indicative as to the way that the material could behave in actual conditions in the incipient stage of fire spreading. Products that meet the requirements of class $E_{f l}$ may be designated for household use (ZL IV). The installation of such samples in roofed buildings entails a considerable risk for the life of the people residing inside.

\section{References}

1. Schoukens G., Advances in Carpet Manufacture, Woodhead Publishing Series in Textiles, 5, p.102-137, (2009)

2. Bocca, B., Forte, G., Petrucci, F., Costantini, S., Izzo, P., Science of the Total Environment, 407, 2183-2190, (2009)

3. Z. Sychta, Stopień palności siedzisk z tworzyw sztucznych oraz traw i bieżni z tworzyw sztucznych w aspekcie bezpieczeństwa pożarowego stadionu (2008).

4. Pietka D., Nawierzchnie syntetyczne na niekrytych obiektach sportowych i rekereacyjnych, Warunki tech. wykonania i odbioru robót budowlanych, ITB, 2016

5. Magnusson S., Macsik J., Resources, Conservation and Recycling, 122, p. 362-372, (2017)

6. Wachtendorf V., Kalbe U., Krüger O., Bandow N., Polymer Testing, 63, p. 621-631, (2017)

7. P. Sandkuehler, E. Torres, Th. Allgeuer, Sports Technology, 3, 52-58, (2010)

8. Wengert, S.,. Gesundheitsgefährdung durch Schadstoffe im Kunstrasen?, Seminar Kunststoffrasen. Eidgenössisches Department des Innern (EDI), Bundesamt für Gesundheit (BAG), Magglingen. 18 (2007)

9. Li X., Berger W., Musante C., Mattina M. I., Chemosphere, 80, p. 279-285, (2010)

10. Li M., Lin D., Zhu L., Environ. Pollut. 173, 97-102, (2013.).

11. Menichini, E., Abate, V., Attias, L., De Luca, S., Di Domenico, A., Fochi, I., Fiorte, G., Iacovella, N., Iamiceli, A.L., Izzo, P., Merli, F., Sci. Total Environ. 409, 49504957 (2011) 
12. Krüger O., Kalbe U., Richter E., Egeler P., Römbke J., Berger W., Environ. Pollut., 175, p. 69-74, (2013)

13. Jim C. Y., Landscape and Urban Planning, 157, p. 561-576, (2017)

14. J. Ekstrand, T. Timpka, M Hagglund, Br J Sports Med, 40, 975-980, (2006),

15. Final report Airside Applications for Artificial Turf, U.S. Department of Transportation, Federal Aviation Administration, NTIS, (2006)

16. Announcement of the Marshall of the Sejm of the Republic of Poland of 8 June 2017 on publication of a consolidated text of the act - the Building Code (Polish Journal of Laws/Dz. U. No. 2017 item 1332)

17. Regulation of the European Parliament and of the Council (EU) No. 305/2011 of 9 March 2011 laying down harmonised conditions for the marketing of construction products and repealing Council Directive 89/106/EEC (the so-called the CPR)

18. Regulation of the Minister of Infrastructure and Building Industru of 14 November 2017 amending the regulation on technical criteria which should be made by buildings and their situation (Polish Journal of Laws/Dz. U. 2017 item 2285)

19. PN-EN 13501 - 1:2010 Fire classification of building products and building elements - Part 1: Classification on the basis of tests of reaction to fire

20. FIFA "Football Studiums, Technical Recomendation and Requirements" Ed. IV, 2007.

21. PN-EN 15947-5:2010 Theatrical pyoitechnic articles class 1, 2 and 3 - Part 5: Requirements for construction and working

22. PN-C-86061:1997 Theatrical pyoitechnic articles. Classification, requirements for safety and test methods

23. FIFA Football Stadiums: Technical recommendations and requirements, Ed. V, 2011.

24. M. Pofit-Szczepanska M., Warunki powstawania $i$ dynamika rozprzestrzeniania sie zjwisk pożarowo-wybuchowych w przemyśle przerobu ropy naftowej (2014).

25. PN EN ISO 9239-1:2010 Testing of reaction to fire of flooring - Part 1: Determination of the burning behaviour using a radiant heat source

26. PN-EN 13238:2011 Reaction to fire tests of building products - Conditioning procedures and geeral rules for selection of substrates

27. PN-EN ISO 11925-2:2010 Reaction to fire tests - Flammability of products subjected to direct operation of the flame - Part 2: Testing under a single flame

28. PN-B-02854:1996 Ochrona przeciwpożarowa budynków - Metoda badania rozprzestrzeniania płomieni po posadzkach podłogowych 